\title{
First report of cucumber mosaic virus subgroups I and II with satellite RNA infecting Nicotiana glauca in Mexico
}

\author{
Candelario Ortega-Acosta ${ }^{1} \cdot$ Daniel L. Ochoa-Martínez ${ }^{1}$ (D) $\cdot$ Javier Hernández-Morales ${ }^{1}$
}

Received: 20 July 2018 / Accepted: 19 February 2019 /Published online: 4 March 2019

(C) Società Italiana di Patologia Vegetale (S.I.Pa.V.) 2019

Keywords Cucumovirus · Subviral RNA $\cdot$ Cucumber mosaic virus $\cdot$ Subgroup I · Subgroup II

Cucumber mosaic virus (CMV) strains are divided into two subgroups (CMV-I and CMV-II), and several strains are associated with a satellite RNA (satRNA) that modulates their replication and pathogenicity (Zitter and Murphy 2009). The presence of CMV-I, CMV-II and satRNA was determined in Nicotiana glauca plants with mosaic, leaf deformation and yellowing symptoms. RT-PCR for detection of CMV-I, CMV-II and satRNA (Chen et al. 2011) was performed on double-stranded RNA obtained from one asymptomatic, and seven symptomatic plants. Both subgroups were detected from three samples showing mosaic, leaf deformation and yellowing, and only CMV-II from four samples with mosaic and leaf deformation; satRNA was amplified from all symptomatic samples. No amplification was observed in the asymptomatic plant. The amplified DNA fragments were sequenced (Macrogen, Korea), and a representative sequence of each subgroup of CMV and satRNA were deposited in the GenBank. BLAST analysis of CMV-I sequence (MH633492) showed a 98\% identity with 242 isolate (AJ585520) from Australia, the CMV-II (MH633495) showed a 99\% identity with "R" isolate (Y18138) from France, and satRNA (MH633497) 93\% identity with isolate To/1991/4.1 (Z75871) from Spain. A CMV-II + satRNA isolate was mechanically inoculated in Nicotiana tabacum, N. glutinosa, and Chenopodium amaranticolor. Five days post inoculation (dpi), necrotic local lesions were observed in C. amaranticolor and after 8 dpi mosaic was observed in $N$. tabacum and $N$. glutinosa, systemic necrosis was also observed in the latter at $14 \mathrm{dpi}$. This is the first report of CMV-I and CMV-II with satRNA infecting N. glauca in Mexico.

\section{Compliance with ethical standards}

Conflict of interest The authors declare that they have no conflict of interest.

Publisher's note Springer Nature remains neutral with regard to jurisdictional claims in published maps and institutional affiliations.

\section{References}

Chen S, Gu H, Wang X, Chen J, Zhu W (2011) Multiplex RT-PCR detection of cucumber mosaic virus subgroups and Tobamoviruses infecting tomato using 18S rRNA as an internal control. Acta Biochim Biophys Sin 43(6):465-471

Zitter TA, Murphy JF (2009) Cucumber mosaic. Plant Health Instruct. https://doi.org/10.1094/PHI-I-2009-0518-01

Daniel L. Ochoa-Martínez

ldaniel@colpos.mx

1 Colegio de Postgraduados, Posgrado en Fitosanidad-Fitopatología, Texcoco, Mexico 